\section{Film Committee}

Dr. R. P. Liston, chairman of the Film Committee, presented its report. The Council agreed to delete the words " who [a panel of expert judges] will pay special regard to the value of the film to the Film Library and the likelihood of its frequent use " from the "Conditions of B.M.A. Film Competition." It was felt that such a provision might make the producer of an excellent film on a medical subject of interest only to a specialist audience reluctant to enter it in the competition in view of its apparently limited appeal, and consequently a good film would be lost to the Film Library.

Council also accepted a recommendation that an additional heading "Audience for Whom Film is Designed" be included in the entry form for the 1959 Film Competition, and that the final adjudicating panel should comprise the Film Committee.

\section{Medico-Legal Film}

The University Grants Committee had informed the Committee that it was unable to assist in the production of a medico-legal film. The Committee felt that it was an important subject and had approached the medical defence societies about the production of such a film.

\section{Charities Committee}

Dr. R. Cove-SMITH presented the report of the Charities Committee. He reported that up to February 13103 covenant forms in respect of the Charities Trust Fund had been received. The net value was $£ 239$ and gross value, after reclaiming tax, $£ 416$ per annum. A further 100 covenant forms earmarked for special funds had also been received.

\section{Draft Annual Report}

Subject to adjustment by the Chairman, in accordance with decisions of the meeting, the Annual Report of Council was approved for submission to Divisions and Branches.

\section{Other Committees}

The reports of the Journal, Catering, Estates, and Public Relations Committees were also dealt with, together with the reports of the Joint Committee of the B.M.A. and the Magistrates' Association and the Joint Committee of the B.M.A. and the Royal College of Nursing.

On the motion of the CHAIRMAN, 437 candidates were elected as members of the Association.

\section{Association Notices}

\section{REPRESENTATIVE BODY 1959-60-ELECTION OF FOUR REPRESENTATIVES OF PUBLIC HEALTH SERVICE MEMBERS}

Notice is hereby given that nominations of candidates for election as representatives of Public Health Service members of the Association in the Representative Body for 1959-60 must be forwarded in writing so as to reach me not later than Saturday, April 25, 1959.

Candidates must be Public Health Service members as defined in By-law 1, and nominations must be by not less than two such members, upon the prescribed form, copies of which can be obtained on application to me.

\section{P. Stevenson,} Secretary.

\section{Diary of Central Meetings}

AprIL

8 Wed. Occupational Health Committee, 10.30 a.m

8 Wed. Deputizing Arrangements Subcommittee, G.M.S. Committee, 2 p.m.

9 Thurs. Executive Subcommittee, Science Committee, 11.30 a.m.

9 Thurs. Staff Side, Committee C, Medical Whitley

Council, 11.30 a.m.

Trainee General Practitioner Scheme Advisory

Committee, G.M.S. Committee, 11.30 a.m.

9 Thurs. Alternative Service Subcommittee, G.M.S. Committee, 2 p.m.

9 Thurs. Science Committee, 2 p.m.

9 Thurs. Committee C, Medical Whitley Council (at 14, Russell Square, London, W.C.), 2.30 p.m.

\section{Branch and Division Meetings to be Held}

Bristol Division.-At Ashton Court Country Club, Beggar Bush Lane, Failand, Monday, April 6, 8.10 p.m., informal reception for members and their guests.

BURNLEY Division.-At Reedley Hall Nurses' Training School, Reedley, Thursday, April 9, 8.30 p.m., joint meeting with Burnley and District Incorporated Law Society. Informal discussion to Medical Evidence."

DewSBURY Division.-At Board Room, Dewsbury General Infirmary, Friday, April 10, 8.30 p.m., B.M.A. Lecture by Mr. A. L. d'Ábreu : " Surgery of the Heart and Great Vessels." EAST Kent Division.-At Chez Laurie Restaurant, Thanet Way, Herne Bay, Thursday, April 9, 7.30 p.m., dinner ; 8.45 p.m. Dr. R. W. Barter: "Recent Advances in Physical Medicine." EAST NorfolK Division.-At Green Lounge, Bell Hotel, Norwich, Wednesday, April 8, 8 for 8.15 p.m., talk by Dr. Grantly Dick-Read, followed by a discussion, on matters obstetrical and others.

EAST Yorkshire Branch.-At Hull Medical Society, 68, Park Street, Hull, Wednesday, April 8, 8.30 p.m., lecture by Dr. Sheila Sherlock: "Recent Advances in Liver Disease."

GlasGow Division.-At Glasgow Regional Office, 9, Lynedoch Crescent, Glasgow, Thursday, April 9, 8.30 p.m., annual meeting GLOUCESTERSHIRE BRANCH.-At Drawing Room, Town Hall, Cheltenham, Thursday, April 9, 6.15 p.m., B.M.A. Lecture by Sir Gordon Gordon-Taylor: "In Retrospect" (illustrated by lantern slides). Dinner will follow at the Moorend Park Hotel. Members and their ladies are invited.

Goole AND SELBY Division.-At the White Elephant, Snaith, Thursday, April 9, 7.30 p.m., address by Mr. W. H. Carlile (H.M. Coroner).

HARROW Division.-At Tithe Farm House, Eastcote Lane, South Harrow, Tuesday, April 7, 8.30 for 8.45 p.m., B.M.A, Lecture by Professor Alan Moncrieff: "Child Care To-day." Wives of members and members of Wembley Division and their wives are invited.

Kensington and Hammersmith Division.-At West London Hospital, Hammersmith Road, W., Tuesday, April 7, 8.30 p.m., symposium : "General Practitioner Anaesthetics."

REIGATE Division.-At Redhill County Hospital, Tuesday, April 7, 8.30 p.m., lecture and film by Mr. J. D. Andrew: "Penguins of Antarctica." Wives of members, and friends, are invited to attend the meeting.

SouTH-EAST EsSEX Division.-At Middleton Hotel, Friday, April 10, 9 p.m., annual buffet dance.

Soutr EsSEX DIvision.-Friday, April 10, visit to Shell Haven. Meet at Training Centre, 12 noon, for lunch at 12.30 p.m., followed by tour of refinery.

SOUTH-WEST ESSEX DIVISION.-At Board Room, Langthorne Hospital, E., Wednesday, April 8, 8.30 p.m., discussion to be opened by Mr. Brian Roberts, M.A. (Daily Telegraph), followed opened by Mr. Brian :"The Press and the Medical Profession." by Dr. J. A. Moody: "The Press and the Medical Profession."
Members of Stratford Division, B.M.A., and members of local branches of Institute of Journalists and National Union of Journalists are invited.

WeSt DeRbYShIRE Division.-At Physiotherapy Department, Whitworth Hospital, Darley Dale, Wednesday, April 8, 8.30 p.m., meeting. Professor W. F. Gaisford: "Paediatrics for General Practitioners."

Wigan Division.-At Prince of Wales Hotel, Southport, Wednesday, April 8, 7.30 for 8 p.m., annual dinner and dance. Non-medical guests invited by members will be welcome.

Corrections.-Dr. A. V. Russell is the chairman of the Amending Acts Committee and not Dr. H. H. D. Sutherland, as reported in last week's Supplement at page 104.

The address of Mr. C. R. S. Jackson, joint honorary secretary of the Section of Ophthalmology at the forthcoming Annual Meeting, should be 1, Melville Street, Edinburgh, and not 3 , Circus Gardens, as printed in the programme (Supplement, March 21, p. 95). 